\title{
The kinetics of nutritional quality changes during winter jujube slices drying process
}

\author{
Yubao Niu ${ }^{1,3,4}$, Shiyu $\mathrm{Wei}^{2}$, Huan Liu ${ }^{1,3,4}$, Yongzhen Zang ${ }^{1,2,3}$, Yuxue Cao ${ }^{1,3,4}$, Rongguang Zhu ${ }^{1,3,4}$, Xia Zheng ${ }^{1,3,4}$, \\ Xuedong Yao, ${ }^{1,3,4, *}$ \\ ${ }^{1}$ College of Mechanical and Electrical Engineering, Shihezi University, Shihezi, China; ${ }^{2}$ College of Mechanical Engineering \\ and Automation, Northeastern University, Shenyang, China; ${ }^{3}$ Key Laboratory of Northwest Agricultural Equipment, \\ Ministry of Agriculture, Shihezi, China; ${ }^{4}$ Key Laboratory of Agricultural Machinery of Corp, Shihezi, China
}

"Corresponding author: Xuedong Yao, College of Mechanical and Electrical Engineering, Shihezi University, Shihezi, China. Email: yaoxuedong@126.com

Submitted: 16 October 2020. Accepted: 13 January 2021. Published: 3 February 2021.

(c) 2021 Codon Publications

OPEN ACCESS (C) (1)(2)

REVIEW ARTICLE

\begin{abstract}
The purpose of this research is to investigate the kinetics of nutrient's change (vitamin C, reducing sugar, and total acidity) of winter jujube slices that are submitted to drying at different temperatures $\left(55,60,65\right.$, and $\left.70^{\circ} \mathrm{C}\right)$ and air velocities $(3,6$, and $9 \mathrm{~m} / \mathrm{s})$ during the air-impingement drying process. Results showed that the content of vitamin $C$ and reducing sugar, and total acidity decreased with increasing drying time. Furthermore, analysis of variance indicated that the drying temperature, air velocity, and time had a significant effect on the loss of vitamin $\mathrm{C}$ and reducing sugar, and on total acidity $(\mathrm{P}<0.05)$. Zero-order, first-order, and Weibull models were used to fit the experimental data, Weibull model was considered as the most suitable one for the degradation kinetics of vitamin $\mathrm{C}$ and reducing sugar, and change of total acidity in samples dried at different temperatures and air velocities. According to the Arrhenius formula, the activation energy of vitamin $C$, reducing sugar, and total acidity change kinetics were 63.78, 36.48, and $153.51 \mathrm{~kJ} / \mathrm{mol}$, respectively. This research can provide some references for enhancing dried product quality in the jujube drying industry.
\end{abstract}

Keywords: activation energy; air velocity; drying temperature; drying time; Weibull model

\section{Introduction}

Jujube is now popular among consumers because of its crispy texture and rich in nutrients. Researches have indicated that jujube is rich in a variety of nutrients (Gao et al., 2011), and thus it is known as the "king of vitamins." However, fresh jujube decays easily due to its high moisture content. Hence, most farmers and factories need preservation techniques to extend the storage period and prolong the shelf-life after harvesting the fresh ones.

Drying is the most common method of food preservation, which can prolong the shelf life by reducing the moisture content (Al Juhaimi et al., 2016; Mujumdar and Law, 2010). Jujube slices drying can contribute to enhance the quality of the dried product and reduce the drying time compared to whole jujubes drying, it can not only use damaged jujube effectively but also make them more convenient to store and transport than the whole jujube.

Doymaz et al. (2016) found that the total color change of the dried jujube fruits increased with the increasing infrared power level, and the Page model was more fitted to the experimental drying data. Chen et al. (2015) found that short- and medium-wave infrared radiation provided dried jujube slices that had brighter color and higher retention of vitamin C compared to hot-air drying. He et al. (2013) evaluated the physical properties of crispy winter jujube dried by explosion puffing drying, 
and they found that the dried products exhibited very close rehydration capacity with those obtained by a combination of freeze-drying and hot air drying, while the dried products had better crispness. Wojdyło et al. (2019) investigated different parameters of combined methods such as pre-drying by hot air drying and finishing drying by vacuum-microwave drying, and found that the content of phenolic substances and antioxidant activity of dried products decreased with the increasing air temperature and material temperature during hot air drying and vacuum-microwave drying, respectively. Gao et al. (2012) analyzed the change of sugar content of jujube after four drying treatments including sun drying, oven drying, microwave drying, and freezedrying, and the results showed that freeze-dried jujubes had higher antioxidant activity than microwave-dried jujubes, but microwave-dried jujubes had higher retentions of protocatechuic acidity, catechin, and epicatechin. Although some scholars studied the change of quality indexes, these researches mainly focused on the drying methods of jujube and the changes of nutritional quality after jujube drying. There are few reports on the dynamic changes in the nutritional quality of jujube slices during drying.

The common nutritional quality indicators of jujube slices mainly cover sugar, acidity, vitamin $\mathrm{C}$, and so on ( $\mathrm{Pu}$ et al., 2017). Vitamin C is one of the main vitamins for the human body, which is an important antioxidant that is linked to a reduction in the incidence of some diseases (Santos and Silva, 2008). Reducing sugar content and total acidity content are also two common nutrition quality indexes of jujube slices, which directly determine the sugar-acidity ratio which is the most direct taste response from consumers to products. Therefore, in this research, vitamin $\mathrm{C}$ content, reducing sugar content, and total acidity content were regarded as the representative indexes to evaluate the nutritional quality of jujube slices.

Air-impingement jet drying technology is an efficient drying method, which has been used in food baking, blanching, and drying in recent years. During the airimpingement jet drying process, a thinner boundary layer between the air and the surface of the product due to the higher air velocity and impinging directly the surface of the product, which leads to the enhancement of heat and mass transfer (Anderson and Singh, 2006; Mujumdar, 2006). The heat transfer coefficient is five-fold higher than the respective with conventional dryers. Meanwhile, the drying rate increases and the drying time decreases (Seyedein et al., 1995). The kinetics of nutritional quality changes (vitamin $\mathrm{C}$, reducing sugar, and total acidity) during the drying process of jujube slices were studied by air-impingement drying, which provides some theoretical support for the jujube drying industry.

\section{Materials and methods}

\section{Experimental materials}

Fresh winter jujubes with the same maturity and similar size were purchased from Shihezi comprehensive wholesale market. All the winter jujubes were stored in a refrigerator at $4 \pm 1^{\circ} \mathrm{C}$ and $96 \pm 2 \%$ relative humidity prior to all experiments. Then the winter jujubes without mechanical damage were washed with tap water for removing the dust on the surface. Excess water on their surface was removed by blowing ambient air. Then the winter jujubes were cut into slab shape with $7.0 \mathrm{~mm}$ as the average thickness by a sharp blade. The moisture content of the samples was $80 \pm 1.0 \%$ on a wet basis, initially (w.b.).

\section{Sample drying}

The air-impingement jet dryer (Drying Technology and Equipment Laboratory of Shihezi University) was employed to drying the samples, as shown in Figure 1. The experiments were performed and the recorded data are given in Table 1. Then the single layer of samples was placed in rows on the drying tray, each row being $40 \pm 0.2 \mathrm{~g}$ as a sample. A sample was collected and weighed

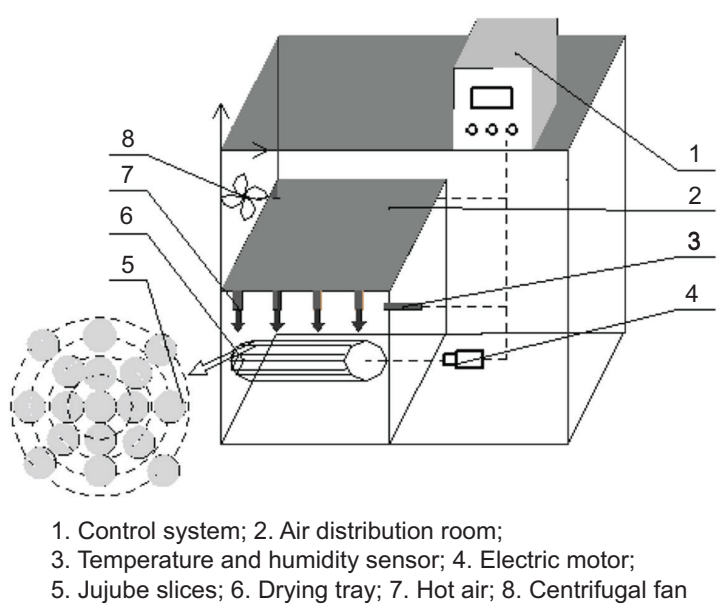

Figure 1. Schematic diagram of pulsed air-jet impingement dryer.

Table 1. Design for the experiments with run conditions included.

\begin{tabular}{lccc} 
Run no. & $\begin{array}{c}\text { Drying temperature } \\
\left({ }^{\circ} \mathrm{C}\right)\end{array}$ & $\begin{array}{c}\text { Air velocity } \\
(\mathbf{m} / \mathbf{s})\end{array}$ & $\begin{array}{c}\text { Pulsation ratio } \\
(\mathrm{r} / \mathrm{min})\end{array}$ \\
\hline 1 & 55 & 6 & 6 \\
2 & 60 & 6 & 6 \\
3 & 65 & 6 & 6 \\
4 & 70 & 6 & 6 \\
5 & 60 & 3 & 6 \\
6 & 60 & 9 & 6 \\
\hline
\end{tabular}


immediately by Electronic Balance every $30 \mathrm{~min}$ during the drying process. The moisture content of the sample was calculated and the samples sealed in the refrigerator until needed. When the moisture content of the sample was less than $20 \%$ (w.b.), the drying process was terminated.

Each sample was crushed and divided into three equal parts after the sample was taken out of the refrigerator and the content of vitamin $C$, reducing sugar, and total acidity was determined, respectively. All experiments were performed in triplicate to ensure the accuracy of the test data.

\section{Moisture content}

The change of moisture content was described as moisture ratio (MR). The calculation of MR was according to the method of Goyal et al. (2007).

$$
\mathrm{MR}=\frac{\mathrm{M}_{\mathrm{t}}-\mathrm{M}_{\mathrm{e}}}{\mathrm{M}_{0}-\mathrm{M}_{\mathrm{e}}}
$$

where, $M_{t}$ represents the moisture content of samples at drying time $t, M_{0}$ is the initial moisture content of samples, and $\mathrm{M}_{\mathrm{e}}$ is the equilibrium moisture content. The values of $M_{e}$ were relatively low compared to $M_{0}$ and $M_{t}$ values, thus Equation (1) was simplified and as expressed in Equation (2).

$$
\mathrm{MR}=\frac{\mathrm{M}_{\mathrm{t}}}{\mathrm{M}_{0}}
$$

\section{Chemical analysis}

Vitamin C content of samples was determined by 2,6-dichloro-indo-phenol titrimetric method described by Caparino et al. (2017) with slight modification. Ten grams (10 g) sample was homogenized in a blender with $100 \mathrm{~mL}$ oxalic acid solution. $10 \mathrm{~mL}$ filtration solution was transferred to a $50 \mathrm{~mL}$ conical flask and titrated with 2,6-dichloro-indo-phenol (0.01 g/100 g solution) until the filtrate was pink for $15 \mathrm{~s}$ without fading. The titration was repeated several times for accuracy.

Reducing sugar content of samples was determined by the official LaneEynone titratable method as described in AOAC. (2005).

The total acidity content of samples was determined by a titration method following the methodology described by Jahan et al. (2019).

\section{Statistical analysis}

Statistical significance of the experiments was determined using a two-way analysis of variance (ANOVA) with $\mathrm{P}<0.05$. The Statistical Product and Service Solutions (SPSS) software is used for this analysis. The mathematical modeling of drying curves and vitamin $\mathrm{C}$, reducing sugar, and total acidity was performed with Origin Pro 8 software.

\section{The kinetic model of quality change}

The quality changes of foods during processing and storage can be described by different kinetic models. The degradation kinetics of vitamin $C$ and reducing sugar, and change of total acidity were assessed with zero-order, first-order, and Weibull distribution models [Equations (3)-(5)].

$$
\begin{gathered}
c_{t}=c_{0}+k_{0} t \\
c_{t}=c_{0} \exp \left(k_{1} t\right) \\
c_{t}=c_{0} \exp \left[-\left(k_{\alpha} t\right)^{\beta}\right]
\end{gathered}
$$

where, $C_{t}$ is the nutrient quality index value at any time; $\mathrm{C}_{0}$ is the initial value of the index; $\mathrm{t}$ is the time, $\mathrm{h} ; \mathrm{k}_{0}$ is the zero-order kinetic reaction rate constant; $k_{1}$ is the firstorder kinetic reaction rate constant; $k_{\alpha}$ is the Weibull distribution kinetic reaction rate constant (Corradini and Peleg, 2004); and $\beta$ is the shape constant.

The effect of temperature on each indicator is in accordance with the Arrhenius equation:

$$
\mathrm{k}=\mathrm{A}_{0} \exp \left(\frac{-\mathrm{E}_{\mathrm{a}}}{\mathrm{RT}}\right)
$$

where, $\mathrm{k}$ is the reaction rate constant; $\mathrm{A}_{0}$ is the Arrhenius constant (frequency factor); $\mathrm{E}_{\mathrm{a}}$ is the activation energy, $\mathrm{J} / \mathrm{mol}$; $\mathrm{R}$ is the universal gas constant, 8.314 $\mathrm{J} /(\mathrm{mol} \cdot \mathrm{K})$; $\mathrm{T}$ is the temperature, $\mathrm{K}$.

Take the logarithm of both sides of the Arrhenius equation:

$$
\ln \mathrm{k}=\frac{-\mathrm{E}_{\mathrm{a}}}{\mathrm{RT}}+\ln \mathrm{A}_{0}
$$

Taking $\ln \mathrm{k}$ as the ordinate and $\mathrm{T}^{-1}$ as the abscissa for the curve. For the straight-line fitting of the obtained result, the slope is $E_{a} R^{-1}$, and the value of $E_{a}$ can be calculated by taking the value of $R$.

\section{Results and Discussion}

\section{Nutrient change curves}

To compare the effect of different drying temperature and air velocity on the dynamics of nutritional quality 
changes of winter jujube slices, the curves of vitamin $C$ versus drying time, reducing sugar versus drying time, and total acidity versus drying time under different processing parameters are shown in Figures 2-7.

\section{Retention of vitamin C}

The fitting curves of vitamin $\mathrm{C}$ versus drying time under different drying temperatures with a constant air velocity of $6 \mathrm{~m} \mathrm{~s}^{-1}$ are shown in Figure 2. It can be seen that the content of vitamin $\mathrm{C}$ decreased with increasing drying time $(\mathrm{P}<0.05)$. That may be due to the higher moisture content during the initial stage of drying, and the higher activity of the enzyme, which accelerated the decrease of vitamin $C$ retention. In all dried samples, the retention rate of vitamin $C$ was less than $46.45 \%$, the highest retention of vitamin $\mathrm{C}$ was obtained at $55^{\circ} \mathrm{C}\left(0.28 \mathrm{~g} 100 \mathrm{~g}^{-1}\right)$. The loss of vitamin $\mathrm{C}$ increased with the increasing drying temperature $(\mathrm{P}<0.05)$. The possible reasons for this phenomenon could be the effect of oxidation and thermal degradation (Hawlader et al., 2006). The heated air inherently exposes the products to oxidation, reducing their vitamin C content (Vega-Gálvez et al., 2008). Similar results were obtained in the drying experiment of Monukka seedless grapes conducted by Xiao et al. (2010), in the drying experiment of red peppers conducted by
Dağhan et al. (2018), and in the drying experiment of kiwifruit by Kaya et al. (2009).

The fitting curves of vitamin $C$ versus drying time under different air velocities with a constant drying temperature of $60^{\circ} \mathrm{C}$ are shown in Figure 3. The vitamin $\mathrm{C}$ content was inversely proportional to the drying time. In all dried samples, the highest retention of vitamin $\mathrm{C}$ was obtained

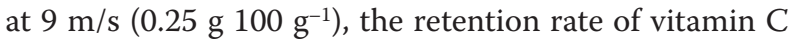
was less than $42.82 \%$. Although the vitamin $C$ content of samples in the initial drying stage was higher at the lower air velocity $(P<0.05)$, a longer drying time was needed, so the final vitamin $C$ retention rate was the lowest.

\section{Retention of reducing sugar}

The fitting curves of reducing sugar versus drying time under different drying temperatures with a constant air velocity of $6 \mathrm{~m} / \mathrm{s}$ are shown in Figure 4 . In the drying process, the reducing sugar content decreased with the increase of drying time $(\mathrm{P}<0.05)$. Reducing sugar retention rates of all dried samples were found lower than $44.32 \%$, and the highest retention of reducing sugar was

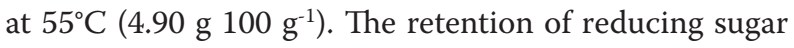
was negatively correlated with the temperature $(\mathrm{P}<$ 0.05). These phenomena were probably due to reducing
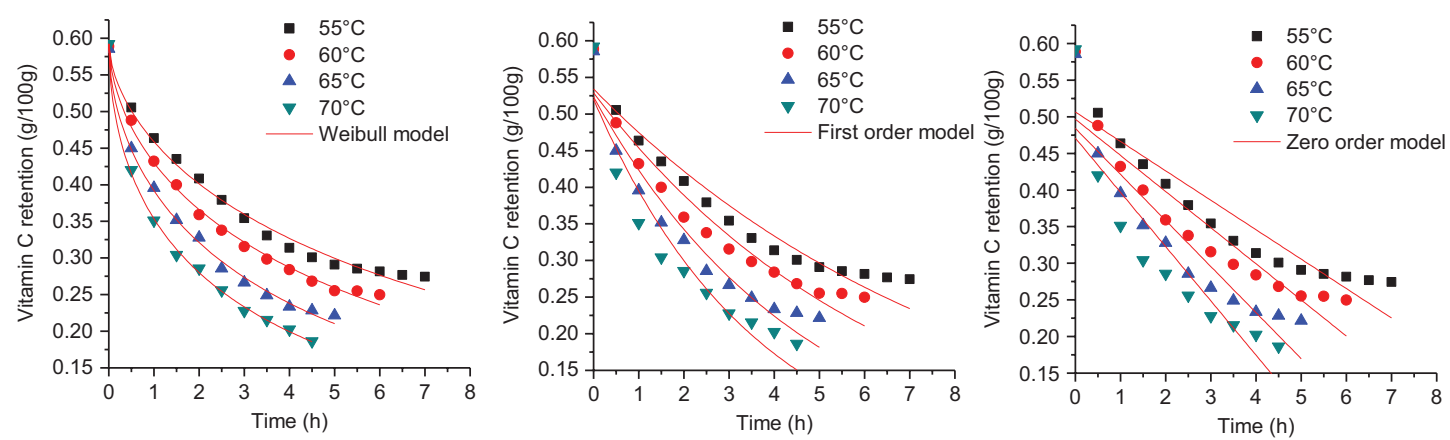

Figure 2. The fitting curves of vitamin $C$ content variation under different drying temperatures with a constant air velocity of $6 \mathrm{~m} / \mathrm{s}$.
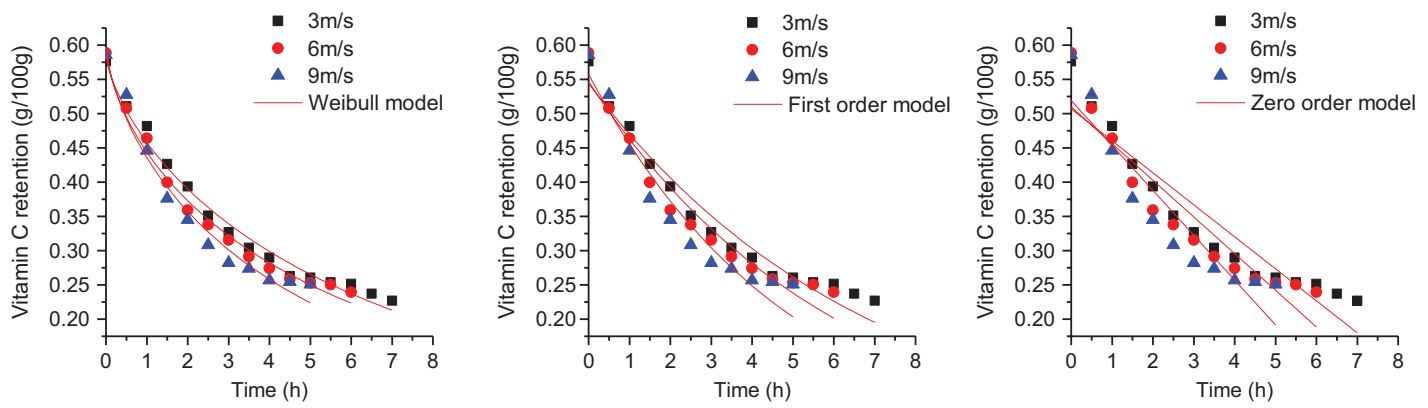

Figure 3. The fitting curves of vitamin $\mathrm{C}$ content variation under different air velocities with a constant drying temperature of $60^{\circ} \mathrm{C}$. 
sugar that occurred in the Maillard reactions under lower temperatures. Reducing sugar binding to amino acids, eventually resulted in the loss of protein content and total sugar, especially reducing sugar (Chen et al., 2012). While at higher drying temperatures, one part of the reducing sugar participated in the Maillard reaction and the other part participated in the caramelization reaction (Boudhrioua et al., 2002).

The fitting curves of reducing sugar versus drying time under different air velocities with a constant drying temperature of $60^{\circ} \mathrm{C}$ are shown in Figure 5. During the drying process, reducing sugar content of dried samples decreased gradually with time. The highest retention of reducing sugar was found at $9 \mathrm{~m} / \mathrm{s}\left(4.8 \mathrm{~g} 100 \mathrm{~g}^{-1}\right)$, and reducing sugar retention rates of all dried samples were lower than $43.74 \%(\mathrm{P}<0.05)$.

\section{Retention of total acidity}

The fitting curves of total acidity versus drying time under different drying temperatures with a constant air velocity of $6 \mathrm{~m} / \mathrm{s}$ are shown in Figure 6. It is shown that the total acidity retention of winter jujube slices decreased slightly with time for the same drying temperature $(\mathrm{P}<0.05)$. The lowest total acidity retention of dried samples was obtained at $55^{\circ} \mathrm{C}\left(0.40 \mathrm{~g} 100 \mathrm{~g}^{-1}\right)$, and
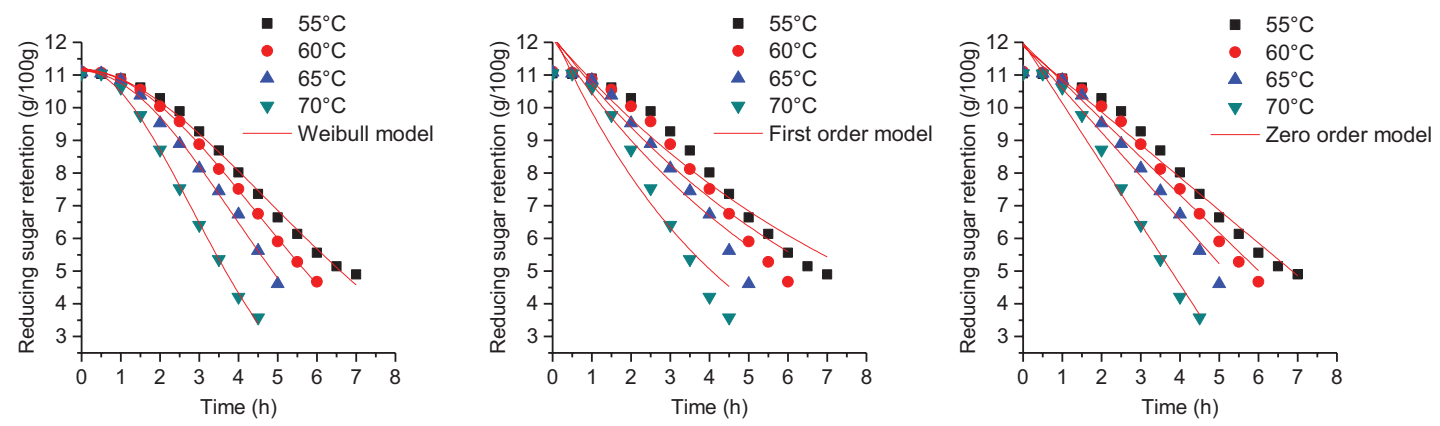

Figure 4. The fitting curves of reducing sugar content variation under different drying temperatures with a constant air velocity of $6 \mathrm{~m} / \mathrm{s}$.
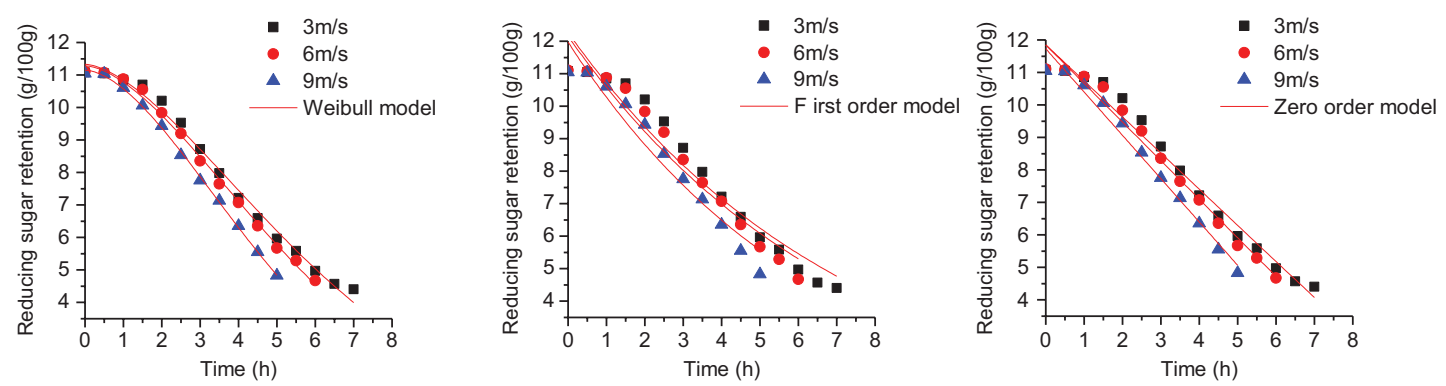

Figure 5. The fitting curves of reducing sugar content variation under different air velocities with a constant drying temperature of $60^{\circ} \mathrm{C}$.
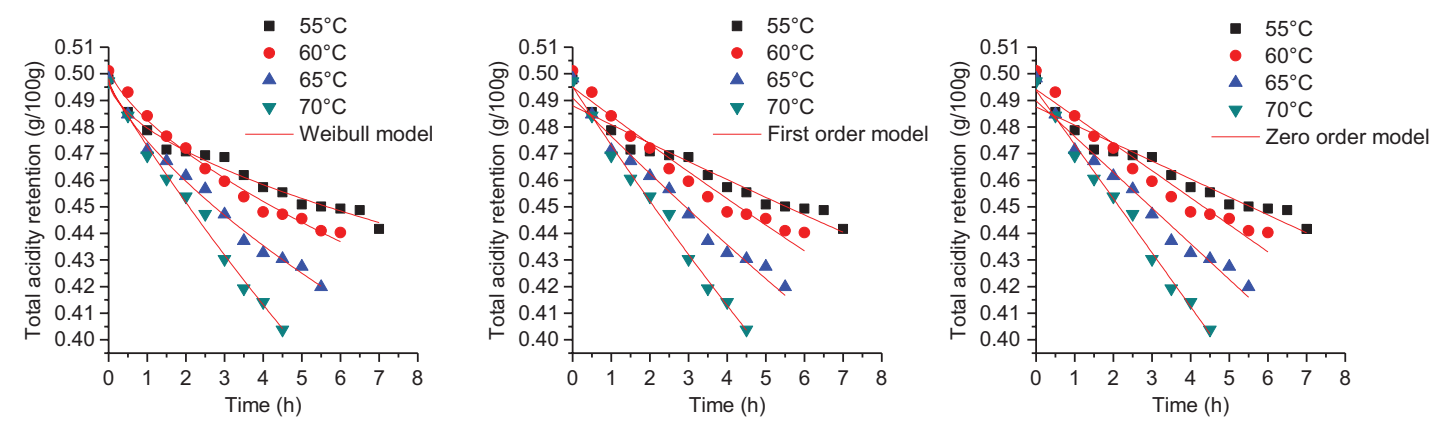

Figure 6. The fitting curves of total acidity content variation under different drying temperatures with a constant air velocity of $6 \mathrm{~m} / \mathrm{s}$. 

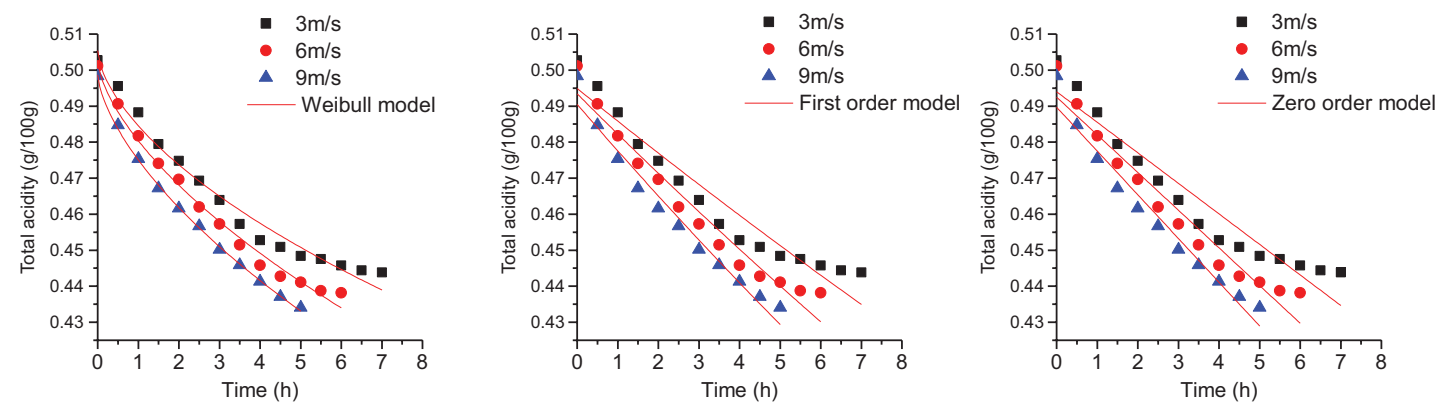

Figure 7. The fitting curves of total acidity content variation under different air velocities with a constant drying temperature of $60^{\circ} \mathrm{C}$.

the retention rates were higher than $81.23 \%(\mathrm{P}<0.05)$. The decrease in acidity may be due to the conversion of the acid into sugars or some other compounds during the drying process, or the utilization of the acid in the respiration process (Prajapati et al., 2011). This result is in agreement with several studies (Ashebir et al., 2009; Fernandes et al., 2018) that reported degradation of total acidity at high temperatures.

The fitting curves of total acidity versus drying time under different air velocities with a constant drying temperature of $60^{\circ} \mathrm{C}$ are shown in Figure 7. The reducing sugar content of dried samples decreased gradually with time. It was shown that the lowest total acidity retention of dried samples was obtained at $9 \mathrm{~m} / \mathrm{s}\left(0.43 \mathrm{~g} 100 \mathrm{~g}^{-1}\right)$, and the retention rates were higher than $87.11 \%(\mathrm{P}<0.05)$. Total acidity retention of dried samples decreased gradually with time.

\section{Significance analysis}

The drying temperatures, time, and air velocities had a significant effect on the vitamin $\mathrm{C}$, reducing sugar, and total acidity content of samples during their drying process as obtained by the two-way ANOVA $(\mathrm{P}<0.05)$.

\section{Degradation kinetics}

\section{Vitamin C degradation kinetics}

The vitamin $C$ degradation kinetic results are displayed in Table 2. Based on the criteria of the highest determination coefficients $\left(R^{2}=0.9892-0.9986\right)$, the Weibull model was selected as the most suitable model for vitamin $\mathrm{C}$ degradation kinetics in samples dried at different temperatures. The values of kinetic constants $\left(k_{\alpha}\right)$ and shape constants $(\beta)$ of the Weibull model were obtained by fitting the experimental data. The $\mathrm{k}_{\alpha}$ values for vitamin $\mathrm{C}$ obtained through the Weibull model were $0.1066,0.1443$, 0.2090 , and 0.2928 at $55,60,65$, and $70^{\circ} \mathrm{C}$, respectively. Lower $k_{\alpha}$ values indicate lower degradation rates or, put
Table 2. The fitting parameters of vitamin $\mathrm{C}$.

\begin{tabular}{lccccc} 
Model & $\mathbf{T}\left({ }^{\circ} \mathbf{C}\right)$ & $\mathbf{V}(\mathbf{m} / \mathbf{s})$ & $\mathbf{k}$ & $\beta$ & $\mathbf{R}^{\mathbf{2}}$ \\
\hline $\mathrm{C}=\mathrm{C}_{0} \exp \left[-\mathrm{k}_{\alpha} \mathrm{t}\right]^{\beta}$ & 55 & 6 & 0.1066 & 0.6106 & 0.9892 \\
Weibull model & 60 & & 0.1443 & 0.5905 & 0.9949 \\
& 65 & & 0.2090 & 0.5799 & 0.9960 \\
& 70 & & 0.2928 & 0.5383 & 0.9986 \\
$\mathrm{C}=\mathrm{C}_{0} \exp \left(\mathrm{k}_{1} \mathrm{t}\right)$ & 55 & 6 & -0.1177 & & 0.9324 \\
First-order & 60 & & -0.1534 & & 0.9260 \\
model & 65 & & -0.2119 & & 0.9205 \\
& 70 & & -0.2755 & & 0.8992 \\
$\mathrm{C}=\mathrm{C}_{0}+\mathrm{k}_{0} \mathrm{t}$ & 55 & 6 & -0.0402 & & 0.8667 \\
Zero-order & 60 & & -0.0493 & & 0.8506 \\
model & 65 & & -0.0629 & & 0.8307 \\
& 70 & & -0.0741 & & 0.7905 \\
$\mathrm{C}=\mathrm{C}_{0} \exp \left[-\mathrm{k}_{\alpha} \mathrm{t}\right]^{\beta}$ & 60 & 3 & 0.1447 & 0.7289 & 0.9847 \\
Weibull model & & 6 & 0.1619 & 0.6723 & 0.9870 \\
& & 9 & 0.1950 & 0.7064 & 0.9671 \\
$\mathrm{C}=\mathrm{C}_{0} \exp \left(\mathrm{k}_{1} \mathrm{t}\right)$ & 60 & 3 & -0.1463 & & 0.9608 \\
First-order & & 6 & -0.1661 & & 0.9467 \\
model & & 9 & -0.2017 & & 0.9352 \\
$\mathrm{C}=\mathrm{C}_{0}+\mathrm{k}_{0} \mathrm{t}$ & 60 & 3 & -0.0467 & & 0.8901 \\
Zero-order & & 6 & -0.0535 & & 0.8693 \\
model & & 9 & -0.0655 & & 0.8490 \\
\hline & & & & &
\end{tabular}

differently, a long time before nutrient collapse (Marfil et al., 2008). The parameter $\mathrm{k}_{\alpha}$ was directly affected by drying temperatures in this study. The degradation rate of vitamin $C$ increased with the drying temperature. The shape constant $\beta$ represents a behavior index, and if $\beta<$ 1 the reaction rate decreases with time (Cunha et al., 1998; Dağhan et al., 2018). The $\beta$ values were 0.6106, $0.5905,0.5799$, and 0.5383 , respectively. The vitamin $\mathrm{C}$ had a higher degradation rate at the beginning of the process. The variation of vitamin $C$ content showed similar changes under different air velocities with a constant drying temperature of $60^{\circ} \mathrm{C}$. The degradation rate of vitamin $\mathrm{C}$ decreased with time during the drying process, 
Table 3. The fitting parameters of reducing sugar.

\begin{tabular}{|c|c|c|c|c|c|}
\hline Model & $\mathrm{T}\left({ }^{\circ} \mathrm{C}\right)$ & $V(\mathrm{~m} / \mathrm{s})$ & k & $\beta$ & $\mathrm{R}^{2}$ \\
\hline \multirow{4}{*}{$\begin{array}{l}\mathrm{C}=\mathrm{C}_{0} \exp \left[-\mathrm{k}_{\alpha} \mathrm{t}\right]^{\beta} \\
\text { Weibull model }\end{array}$} & 55 & 6 & 0.1342 & 1.7943 & 0.9956 \\
\hline & 60 & & 0.1566 & 1.9588 & 0.9994 \\
\hline & 65 & & 0.1836 & 1.9982 & 0.9958 \\
\hline & 70 & & 0.2435 & 1.9169 & 0.9982 \\
\hline \multirow{4}{*}{$\begin{array}{l}C=C_{0} \exp \left(k_{1} t\right) \\
\text { First-order } \\
\text { model }\end{array}$} & 55 & 6 & -0.1149 & & 0.9324 \\
\hline & 60 & & -0.1298 & & 0.9260 \\
\hline & 65 & & -0.1483 & & 0.9205 \\
\hline & 70 & & -0.2224 & & 0.8992 \\
\hline \multirow{4}{*}{$\begin{array}{l}\mathrm{C}=\mathrm{C}_{0}+\mathrm{k}_{0} \mathrm{t} \\
\text { Zero-order } \\
\text { model }\end{array}$} & 55 & 6 & -1.0015 & & 0.8667 \\
\hline & 60 & & -1.1574 & & 0.8506 \\
\hline & 65 & & -1.3387 & & 0.8307 \\
\hline & 70 & & -1.8484 & & 0.7905 \\
\hline \multirow{3}{*}{$\begin{array}{l}\mathrm{C}=\mathrm{C}_{0} \exp \left[-\mathrm{k}_{\alpha} \mathrm{t}\right]^{\beta} \\
\text { Weibull } \\
\text { model }\end{array}$} & 60 & 3 & 0.1465 & 1.6270 & 0.9914 \\
\hline & & 6 & 0.1573 & 1.6685 & 0.9963 \\
\hline & & 9 & 0.1780 & 1.7108 & 0.9987 \\
\hline \multirow{3}{*}{$\begin{array}{l}C=C_{0} \exp \left(k_{1} t\right) \\
\text { First-order } \\
\text { model }\end{array}$} & 60 & 3 & -0.1349 & & 0.9441 \\
\hline & & 6 & -0.1382 & & 0.9441 \\
\hline & & 9 & -0.1529 & & 0.9418 \\
\hline \multirow{3}{*}{$\begin{array}{l}\mathrm{C}=\mathrm{C}_{0}+\mathrm{k}_{0} \mathrm{t} \\
\text { Zero-order } \\
\text { model }\end{array}$} & 60 & 3 & -1.1113 & & 0.9767 \\
\hline & & 6 & -1.1872 & & 0.9800 \\
\hline & & 9 & -1.3328 & & 0.9807 \\
\hline
\end{tabular}

and vitamin $\mathrm{C}$ had a faster degradation rate at higher air velocities.

\section{Reducing sugar degradation kinetics}

The reducing sugar degradation kinetic results are given in Table 3. Based on the criteria of the highest determination coefficients $\left(R^{2}=0.9956-0.9994\right)$, the Weibull model was selected as the most suitable model for reducing sugar degradation kinetics in dried samples at different temperatures. The shape constant $\beta>1$, the degradation rate of reducing sugar increased with time. The $k_{\alpha}$ values for reducing sugar obtained through the Weibull model were $0.1342,0.1566,0.1836$, and 0.2432 at $55,60,65$, and $70^{\circ} \mathrm{C}$, respectively. Reducing sugars had a higher degradation rate at higher air velocities. The variation of reducing sugar content showed similar changes under different air velocities with a constant drying temperature of $60^{\circ} \mathrm{C}$. The degradation rate of reducing sugar increased gradually during the drying process and reducing sugar had a faster degradation rate at higher air velocities.

\section{Total acidity change kinetics}

The total acidity change kinetic results are as shown in Table 4. Based on the criteria of the highest determination coefficients $\left(R^{2}=0.9806-0.9903\right)$, the Weibull model was selected as the most suitable model to total acidity change kinetics in samples dried at different temperatures. The values of kinetic constants $\left(k_{\alpha}\right)$ and shape constants $(\beta)$ of the Weibull model were obtained by fitting the experimental data. The $\mathrm{k}_{\alpha}$ values for total acidity obtained through the Weibull model were 0.1066 , $0.1443,0.2090$, and 0.2928 at $55,60,65$, and $70^{\circ} \mathrm{C}$, respectively. The change rate of total acidity increased with the drying temperature. The $\beta$ values were found 0.6106 , $0.5905,0.5799$, and 0.5383 , and the total acidity had a higher change rate at the beginning of the process. The variation of total acidity content showed similar change under different air velocities with a constant drying temperature of $60^{\circ} \mathrm{C}$. The change rate of total acidity slowed down during the drying process, and total acidity had a faster change rate at higher air velocities.

The Weibull model has an interesting potential for describing microbial, enzymatic, and chemical degradation kinetics (Cunha et al., 1998). In recent years, it has been widely used to describe the changes in quality during drying, such as the drying kinetics (Aghbashlo et al., 2010; Uribe et al., 2011), the rehydration kinetics (Akar and Barutçu, 2019; Goula and Adamopoulos,

Table 4. The fitting parameters of total acidity.

\begin{tabular}{|c|c|c|c|c|c|}
\hline Model & $\mathrm{T}\left({ }^{\circ} \mathrm{C}\right)$ & $V(\mathrm{~m} / \mathrm{s})$ & k & $\beta$ & $\mathbf{R}^{2}$ \\
\hline \multirow{4}{*}{$\begin{array}{l}C=C_{0} \exp \left[-k_{\alpha} t\right]^{\beta} \\
\text { Weibull model }\end{array}$} & 55 & 6 & 0.0034 & 0.5819 & 0.9806 \\
\hline & 60 & & 0.0095 & 0.6845 & 0.9864 \\
\hline & 65 & & 0.0166 & 0.7396 & 0.9892 \\
\hline & 70 & & 0.0427 & 0.9603 & 0.9903 \\
\hline \multirow{4}{*}{$\begin{array}{l}C=C_{0} \exp \left(k_{1} t\right) \\
\text { First-order } \\
\text { model }\end{array}$} & 55 & 6 & -0.0146 & & 0.9352 \\
\hline & 60 & & -0.0221 & & 0.9575 \\
\hline & 65 & & -0.0298 & & 0.9735 \\
\hline & 70 & & -0.0454 & & 0.9812 \\
\hline \multirow{4}{*}{$\begin{array}{l}\mathrm{C}=\mathrm{C}_{0}+\mathrm{k}_{0} \mathrm{t} \\
\text { Zero-order model }\end{array}$} & 55 & 6 & -0.0402 & & 0.9302 \\
\hline & 60 & & -0.0493 & & 0.9497 \\
\hline & 65 & & -0.0629 & & 0.9673 \\
\hline & 70 & & -0.0741 & & 0.9899 \\
\hline \multirow{3}{*}{$\begin{array}{l}C=C_{0} \exp \left[-k_{\alpha} t\right]^{\beta} \\
\text { Weibull model }\end{array}$} & 60 & 3 & 0.0061 & 0.6198 & 0.9737 \\
\hline & & 6 & 0.0090 & 0.6587 & 0.9882 \\
\hline & & 9 & 0.0104 & 0.6626 & 0.9987 \\
\hline \multirow{3}{*}{$\begin{array}{l}C=C_{0} \exp \left(k_{1} t\right) \\
\text { First-order } \\
\text { model }\end{array}$} & 60 & 3 & -0.0184 & & 0.9269 \\
\hline & & 6 & -0.0228 & & 0.9532 \\
\hline & & 9 & -0.0266 & & 0.9646 \\
\hline \multirow{3}{*}{$\begin{array}{l}\mathrm{C}=\mathrm{C}_{0}+\mathrm{k}_{0} \mathrm{t} \\
\text { Zero-order } \\
\text { model }\end{array}$} & 60 & 3 & -0.0085 & & 0.9172 \\
\hline & & 6 & -0.0105 & & 0.9446 \\
\hline & & 9 & -0.0122 & & 0.9575 \\
\hline
\end{tabular}


2009), the changing kinetics of color (Ong et al., 2012; Yang et al., 2018), and the degradation of vitamin C (Santos and Silva, 2009; Wang et al., 2018), of total carotenoids and total polyphenols (Eim et al., 2013). Desirable fitting results were obtained in this research with the application of the Weibull model in the degradation of vitamin $\mathrm{C}$ and reducing sugar, and change of total acidity.

\section{Activation energy for Weibull model parameters}

Arrhenius plots of the natural logarithm of the rate constant (k) versus the inverse of $\mathrm{T}(\mathrm{K})$ for vitamin $\mathrm{C}$, reducing sugar, and total acidity are shown in Figure 8 . The activation energy is related to the slope of this graph and seems that the temperature dependence of the drying rate constant $(\mathrm{k})$ was fitted to a linear model. The $\mathrm{E}_{\mathrm{a}}$ values of vitamin $C$, reducing sugar, and total acidity were found to be $63.78,36.48$, and $153.51 \mathrm{~kJ} / \mathrm{mol}$, respectively. Activation energy usually indicates the energy required for a reaction to reach the activation state (Qiu et al., 2018), the higher activation energy suggests the harder degradation of the nutrient caused by drying, and a higher temperature can accelerate the process mentioned above (Zhou et al., 2017).

\section{Discussions}

This study described the changes of vitamin $C$, reducing sugar, and total acidity of jujube slices during the drying process and appropriate models were fitted with experimental data. However, the detection process of nutrients is complicated and easy to be affected by unexpected conditions. The indices such as moisture content and color which are easily monitored can serve to predict the variation of the nutritional components during drying if the correlation between them can be established.

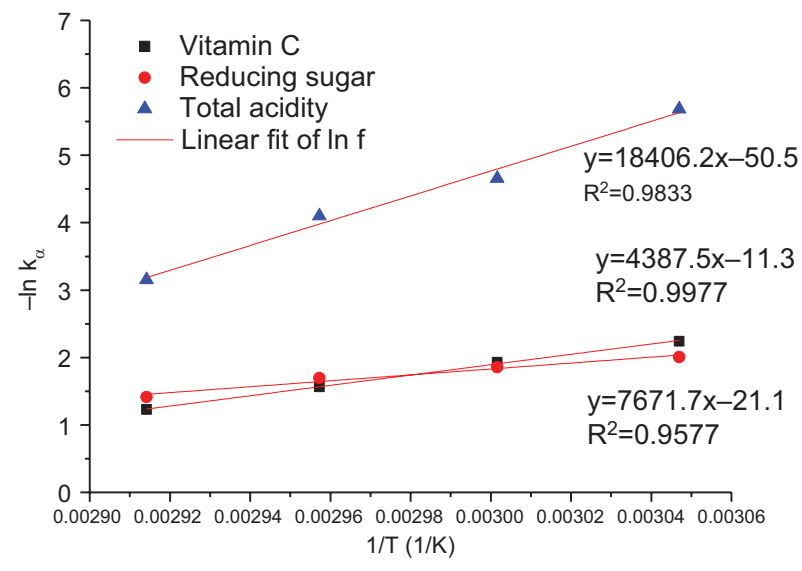

Figure 8. The fitting diagram of vitamin C, reducing sugar, and total acidity.

\section{Conclusions}

In this paper, the kinetics of nutritional quality changes of winter jujube slices during drying at different temperatures and air velocities were studied. Within the range of experimental conditions, the results were showed that: the retention of vitamin $\mathrm{C}$, reducing sugar, and total acidity of winter jujube slices decreased during the drying process. Thereby, drying temperatures, time, and air velocity had a significant effect on the preserving rate of vitamin $C$, reducing sugar, and total acidity.

Weibull model was selected as the most suitable model for vitamin $C$, reducing sugar, and total acidity degradation kinetics in samples dried at different temperatures and air velocities. According to the Arrhenius formula, the activation energy of thermal degradation of vitamin $\mathrm{C}$, reducing sugar, and total acidity were $63.78,36.48$, and $153.51 \mathrm{~kJ} / \mathrm{mol}$, respectively.

\section{Acknowledgments}

This study was supported by the Natural Science Fund of China (31960488).

\section{References}

Aghbashlo M, Kianmehr MH, Hassan-Beygi SR. Drying and rehydration characteristics of sour cherry (Prunus cerasus 1.). J Food Process Preserv. 2010;34(3):351-65. https//doi. org/10.1111/j.1745-4549.2008.00310.x

Akar G, Barutçu MI. Color change, ascorbic acid degradation kinetics, and rehydration behavior of kiwifruit as affected by different drying methods. J Food Process Eng. 2019;42(3):e13011. https// doi.org/10.1111/jfpe.13011

Al Juhaimi F, Ulsu N, Bozkurt D, Ghafoor K, Babiker EE, Özcan MM. Effects of oven and microwave drying on phenolic contents and antioxidant activities in four apple cultivars. Qual Assur Saf Crop Food 2016;8(1):51-5. https//doi.org/10.3920/ QAS2014.0468

Anderson BA, Singh RP. Modeling the thawing of frozen foods using air impingement technology. Int J Refrig. 2006;29(2):294-304. https//doi.org/10.1016/j.ijrefrig.2005.05.003

AOAC. Official methods of analysis of Analytical Chemists International. 18th ed. Gathersburg, MD: USA Official Methods; 2005.

Ashebir D, Jezik K, Weingartemann H, Gretzmacher R. Change in color and other fruit quality characteristics of tomato cultivars after hot-air drying at low final-moisture content. Int J Food Sci Nutr. 2009;60(7):308-15. https//doi. org/10.1080/09637480903114128

Boudhrioua N, Michon C, Cuvelier G, Bonazzi C. Influence of ripeness and air temperature on changes in banana texture during 
drying. J Food Eng. 2002;55(2):115-21. https//doi.org/10.1016/ S0260-8774.(02)00025-0

Caparino OA, Nindo CI, Tang J, Sablani SS, Chew BP, Mathison BD, et al. Physical and chemical stability of refractance window-dried mango (Philippine 'Carabao' var.) powder during storage. Drying Technol. 2017;35(1):25-37. https://doi.org/10.1 080/07373937.2016.1157601

Chen Q, Bi J, Wu X, Yi J, Zhou L, Zhou Y. Drying kinetics and quality attributes of jujube (Zizyphus jujuba Miller) slices dried by hot-air and short- and medium-wave infrared radiation. LWTFood Sci Technol. 2015;64:759-66. https//doi.org/10.1016/j. lwt.2015.06.071.

Chen XM, Kitts DD. Characterization of antioxidant and antiinflammatory activities of bioactive fractions recovered from a glucose-lysine Maillard reaction model system. Mol Cell Biochem. 2012;364:147-57. https//doi.org/10.1007/s11010-011-1213-7

Corradini MG, Peleg M. A model of non-isothermal degradation of nutrients, pigments and enzymes. J Sci Food Agric. 2004;84(3):217-26. https//doi.org/10.1002/jsfa.1647

Cunha LM, Oliveira F, Oliveira JC. Optimal experimental design for estimating the kinetic parameters of processes described by the Weibull probability distribution function. J Food Eng. 1998;37(2):175-91. https//doi.org/10.1016/ S0260-8774.(98)00085-5

Dağhan Ş, Yıldırım A, Yılmaz FM, Karaaslan M. The effect of temperature and method of drying on isot (urfa pepper) and its vitamin C degradation kinetics. Italian J Food Sci. 2018;30(3):504-21. https//doi.org/10.14674/IJFS-1070

Doymaz İ, Karasu S, Baslar M. Effects of infrared heating on drying kinetics, antioxidant activity, phenolic content, and color of jujube fruit. J Food Meas Charact. 2016;10:283-91. https//doi. org/10.1007/s11694-016-9305-4

Eim VS, Urrea D, Rosselló C, García-Pérez JV, Femenia A, Simal S. Optimization of the drying process of carrot (Daucus carotav. nantes) on the basis of quality criteria. Drying Technol. 2013;31(8):951-62. https//doi.org/10.1080/07373937.2012.707162

Fernandes L, Casal S, Pereira JA, Saraiva JA, Ramalhosa E. Effects of different drying methods on the bioactive compounds and antioxidant properties of edible centaurea (Centaurea cyanus) petals. Braz J Food Technol. 2018;21:e2017211. https//doi. org/10.1590/1981-6723.21117

Gao QH, Wu CS, Wang M, Xu BN, Du LJ. Effect of drying of jujubes (Ziziphus jujuba Mill.) on the contents of sugar, organic aciditys, $\alpha$-tocopherol, $\beta$-carotene, and phenolic compounds. J Agric Food Chem. 2012;60(38):9642-8. https//doi.org/10.1021/ jf3026524

Gao QH, Wu PT, Liu JR, Wu CS, Parry JW, Wang M. Physicochemical properties and antioxidant capacity of different jujube (Ziziphus jujuba Mill.) cultivars grown in loess plateau of China. Sci Hortic. 2011;130(1):67-72. https//doi.org/10.1016/J. SCIENTA.2011.06.005

Goula AM, Adamopoulos KG. Modeling the rehydration process of dried tomato. Drying Technol. 2009;27(10):1078-88. https//doi. org $/ 10.1080 / 07373930903218677$

Goyal RK, Kingsly ARP, Manikantan MR, Ilyas SM. Mathematical modelling of thin layer drying kinetics of plum in a tunnel dryer. J Food Eng. 2007;79(1):176-80. https//doi.org/10.1016/j. jfoodeng.2006.01.041

Hawlader MNA, Perera CO, Tian M, Yeo KL. Drying of guava and papaya: Impact of different drying methods. Drying Technol. 2006;24 (1):77-87. https//doi.org/10.1080/07373930500538725

He X, Liu J, Cheng Ll, Wang Bj. Quality properties of crispy winter jujube dried by explosion puffing drying. Int J Food Eng. 2013;9(1):99-106. https//doi.org/10.1515/ijfe-2012-0157

Jahan R, Islam M, Akter F, Alim M, Islam M. Mechanical and osmotic dehydration behavior of pineapple and retention of vitamin C. Fundam Appl Agric. 2019;4(1):723- 34. https//doi. org/10.5455/faa. 15862

Kaya A; Aydin O; Kolayli S. Effect of different drying conditions on the vitamin $\mathrm{C}$ (ascorbic acid) content of Hayward kiwifruits (Actinidia deliciosa Panch). Food Bioprod Processing. 2010;88:165-73. https//doi.org/10.1016/j.fbp.2008.12.001.

Marfil PHM, Santos EM, Telis VRN. Ascorbic acid degradation kinetics in tomatoes at different drying conditions. LWT-Food Sci Technol. 2008;41(9):1642-7. https//doi.org/10.1016/j. lwt.2007.11.003

Mujumdar AS. Handbook of industrial drying. Boca Raton: CRC Press; 2006.

Mujumdar AS, Law CL. Drying technology: Trends and applications in postharvest processing. Food Bioprocess Technol. 2010;3(6):843-52. https//doi.org/10.1007/s11947-010-0353-1

Ong SP, Law CL, Hii CL. Effect of pre-treatment and drying method on colour degradation kinetics of dried salak fruit during storage. Food Bioprocess Technol. 2012;5(6):2331-41. https//doi. org/10.1007/s11947-011-0647-y

Prajapati VK, Nema PK, Rathore SS. Effect of pretreatment and drying methods on quality of value-added dried aonla (Emblica officinalis Gaertn) shreds. J Food Sci Technol. 2011;48(1):45-52. http://dx.doi.org/10.1007/s13197-010-0124-z.

Pu YF, Ding T, Wang WJ, Xiang YJ, Ye X, Li M, et al. Effect of harvest, drying and storage on the bitterness, moisture, sugar, free amino acidities and phenolic compounds of jujube fruit (Zizyphus jujube cv. Junzao). J Sci Food Agric. 2017;98(02):62834. https//doi.org/10.1002/jsfa.8507

Qiu G, Wang D, Song X, Deng Y, Zhao Y. Degradation kinetics and antioxidant capacity of anthocyanins in air-impingement jet dried purple potato slices - ScienceDirect. Food Res Int. 2018;105:121-28. https//doi.org/10.1016/j.foodres.2017.10.050

Santos PHS, Silva MA. Retention of vitamin C in drying processes of fruits and vegetables: A review. Drying Technol. 2008;26:142137. https//doi.org/10.1080/07373930802458911

Santos PHS, Silva MA. Kinetics of 1-ascorbic acid degradation in pineapple drying under ethanolic atmosphere. Drying Technol. 2009;27(9):947-54. https//doi.org/10.1080/ 07373930902901950

Seyedein SH, Hasan M, Mujumdar AS. Turbulent flow and heat transfer from confined multiple impinging slot jet. Numeri Heat Transfer. 1995;27(1):35-51. https//doi.org/10.1080/ 10407789508913687

Uribe E, Vega-Gálvez A, Scala KD, Oyanadel R, Miranda M. Characteristics of convective drying of pepino fruit (Solanum muricatum ait.): Application of Weibull distribution. Food 
Bioprocess Technol. 2011;4(8):1349-56. https//doi.org/10.1007/ s11947-009-0230-y

Vega-Gálvez A, Lemus-Mondaca R, Bilbao-Sáinz C, Fito P, Andrés A. Effect of air drying temperature on the quality of rehydrated dried red bell pepper (var. Lamuyo). J Food Eng. 2008;85(1):4250. https//doi.org/10.1016/j.jfoodeng.2007.06.032

Wang J, Yang XH, Mujumdar AS, Fang XM, Zhan Q, Zheng ZA, et al. Effects of high-humidity hot air impingement blanching (HHAIB) pretreatment on the change of antioxidant capacity, the degradation kinetics of red pigment, ascorbic acid in dehydrated red peppers during storage. Food Chem. 2018;259:65-72. https//doi.org/10.1016/j.foodchem.2018.03.123

Wojdyło A, Lech K, Nowicka P, Hernández F, Figiel A, CarbonellBarrachina Á. Influence of different drying techniques on phenolic compounds, antioxidant capacity and colour of Ziziphus jujube Mill. Fruits. Molecules. 2019;24:2361. https//doi. org/10.3390/molecules24132361

Xiao HW, Pang CL, Wang LH, Bai JW, Yang WX, Gao ZJ. Drying kinetics and quality of Monukka seedless grapes dried in an air-impingement jet dryer. Biosys Eng. 2010;105(2):233-40. https//doi.org/10.1016/j.biosystemseng.2009.11.001

Yang XH, Deng LZ, Mujumdar AS, Xiao HW, Zhang Q, Kan Z. Evolution and modeling of colour changes of red pepper (Capsicumannuum L.) during hot air drying. J Food Eng. 2018;231:101-8. https//doi.org/10.1016/j.jfoodeng.2018.03.013

Zhou M, Chen Q, Bi J, Wang Y, Wu X. Degradation kinetics of cyanidin 3-O-glucoside and cyanidin 3-O-rutinoside during hot air and vacuum drying in mulberry (Morus alba L.) fruit: A comparative study based on solid food system. Food Chem. 2017;229: 574-9. https//doi.org/10.1016/j.foodchem.2017.02.131 